\title{
Evaluation of potential meteorological triggers of large landslides in sensitive glaciomarine clay, eastern Canada
}

\author{
D. Gauthier and D. J. Hutchinson \\ Department of Geological Sciences and Geological Engineering, Queen's University 36 Union St., Kingston, ON, K7L 1N6, \\ Canada
}

Correspondence to: D. Gauthier (gauthier@geol.queensu.ca)

Received: 17 February 2012 - Revised: 19 June 2012 - Accepted: 27 August 2012 - Published: 14 November 2012

\begin{abstract}
Heavy rains spread over some interval preceding large landslides in sensitive glaciomarine clay in eastern Canada are often noted as a triggering or causative factor in case studies or research reports for individual landslides, although the quantity or duration of the triggering rain event has never been characterized adequately. We selected five large landslide events that occurred in the glaciomarine clay in eastern Canada, and calculated cumulative antecedent precipitation for intervals ranging between one and 365 days preceding each event. We also calculated the antecedent precipitation values for every other day in the record, and computed the relative rank of the landslide day within the complete record. Our results show that several intervals for each landslide event are highly ranked - including those preceding a presumably earthquake-triggered landslide - but overall the rankings were highly variable, ranging between $99 \%$ and $6 \%$. The set of highest-ranking intervals are unique for each event, including both short and long-term cumulative precipitation. All of the landslides occurred in the spring months, and the release of sequestered surface and ground water during the spring ground thaw may be related to the timing of the large landslides, so that the evolution of ground frost in the early winter may be of interest for landslide prediction. We found no simple precipitation threshold for triggering large landslides in sensitive glaciomarine clay in eastern Canada, suggesting that some complex temporal and spatial combination of pre-conditions, external energy (e.g. earthquakes), precipitation triggers and other factors such as ground frost formation and thaw are required to trigger a landslide.
\end{abstract}

\section{Introduction}

In a comprehensive analysis of landslide types and processes, Cruden and Varnes (1996) cited intense rainfall, rapid snowmelt, and prolonged exceptional precipitation as primary physical factors leading to landslides in general. In the same volume, Wieczorek (1996) made the distinction between the causes and "triggers" of landslides. Causes are the necessary preconditions for unstable slopes or soils, e.g. stratigraphy, fatigue, permeability, etc. Triggers are those external energy inputs that have a direct or immediate impact on the stability of a slope or soil layer(s), e.g. rain, earthquake, erosion, blasting, etc. In general, intense rainfall is often considered to be the most important trigger of landslides, followed by rapid snowmelt and water level change. Each of these are thought to destabilize soils by altering porewater pressures and hydraulic gradients within the soil column; however, those effects are much better documented for shallow landslides on steep slopes or for debris flows than for deep-seated landslides (e.g. Guzzetti et al., 2008). Guzzetti et al. $(2007,2008)$ and Bunce (2008) provide detailed reviews of known empirical relationships between meteorological triggers and landslides, and discuss landslide warning systems in use worldwide. In Canada, multi-factor indices have been developed for meteorological and general hydrological landslide triggers (e.g. Jakob and Weatherly, 2003; Jakob et al., 2006), and some private companies operate warning or protection systems based on precipitation thresholds (e.g. CP Rail; Bunce, 2008). None of these were developed for application to sensitive clay soils in eastern Canada.

In this paper, we investigate the empirical relationship between precipitation and other possible meteorological triggering factors and large landslides in sensitive glaciomarine 
clay in eastern Canada. Cruden and Varnes (1996) suggested the terms earth flow, earth slide, and earth spread to describe these, although here we do not differentiate. Recent advances in identifying the a priori causes of instability of these deposits (e.g. Hugenholtz and Lacelle, 2006; Quinn et al., 2010, 2011a) have improved the ability of engineers and planners to predict the most likely locations of future landslides, although predicting the timing of these events with any reasonable precision often remains elusive. We focus on the possible meteorological triggers for large (i.e. greater than $10^{6} \mathrm{~m}^{3}$ ) landslides in sensitive clay glaciomarine soils of eastern Canada. The purpose is to attempt a quantification of the long-held notion that rainfall, snowmelt, and other meteorological factors are somehow related the occurrence of large landslides in eastern Canada. It is intended to be a nonparametric, empirical study; we hope the results can provide some insights on the mechanics of sensitive clay landslide release and inputs into the theoretical models that describe these events.

\section{Study area}

Fransham and Gadd (1977) provided detailed maps and descriptions of the soils associated with landslides in the Ottawa River valley in the basin of the former Champlain Sea, which also includes glaciomarine clays located in the western part of the St. Lawrence River valley. Figure 1 shows the main geographical features of the study area, and the extent of the glaciomarine deposits. Some of the findings of Fransham and Gadd (1977) may apply to the eastern soils as well, although mechanical and material differences are known to exist between basins (e.g. Demers, 2001). The lowland areas around the St. Lawrence and Ottawa River valleys were inundated by seawater at the time of the most recent glacial retreat approximately $10000 \mathrm{yr}$ ago, thereby forming the relatively short-lived marine seas, the Champlain being the western-most of these. Coarser-grained deltaic sands were deposited in fresher waters proximal to the ice-front along the inland margin of the seas, while fine-grained sediment was deposited into more distal distal parts. The fine-grained deposits are typically silty clay to clayey silt in the Ottawa area (Fransham and Gadd, 1977); Champlain or "Leda" clay is the generic term for these soils, although the latter is mostly a colloquialism at present. In general, the landslidesusceptible glaciomarine deposits in eastern Canada are characterized by high moisture content (often in excess of the liquid limit), and by their often high sensitivity resulting from their relatively high intact shear strength and often negligible remoulded strength. These properties develop because of flocculated texture, high void ratio, weak bonded structure, and possibly leaching of electrolytic pore water and bond dissolution in the clay (Mitchell and Klugman, 1979; Quigley, 1980; Torrance, 1983, 1999). A characteristic feature of the highly sensitive or "quick" clays is their propensity to liquefy and flow when remoulded during landsliding.

The mechanics of large landslides in sensitive clay deposits has been studied in detail (e.g. Bjerrum, 1955; Eden and Mitchell, 1970; Mitchell and Markell, 1974; Carson, 1966), although no universal consensus on how they occur has arisen. Even the most basic question of retrogressive versus progressive failure processes remains open (e.g. Lo, 1972; Quinn et al., 2011b; Locat et al., 2011). Quinn et al. (2011b) proposed a fracture mechanics model for all large landslides in sensitive clay, while Locat et al. (2011) make the distinction between progressive failure in "lateral spread" landslides, and retrogressive failure in "earthflows".

The effect of precipitation and other hydrological processes on stability has been attributed to a temporary rise in pore pressure causing deformation, followed by complete failure due to large volumes of water infiltrating desiccation cracks near the surface (Eden and Mitchell, 1970; Paul, 1971). Others have considered the role of piezometric pressure distributions and the interaction of groundwater between the clay and any overlying permeable sandy layers within or below it (Donovan, 1978), the specifics of groundwater flow and model inputs for stability analyses (Lafleur and Lefebvre, 1980), or groundwater pressures and effective stress in relation to underlying topography (Lefebvre, 1986). Precipitation (or its runoff) was discounted as a trigger for several landslides in eastern Canada (e.g. Crawford and Eden, 1963; Locat et al., 2008), while Lebuis et al. (1983) discuss an internal government report which found that $80 \%$ of retrogressive landslides (larger than 1 ha) in Quebec between 1840 and 1980 were triggered by riverbank erosion and localized slope failures (often during high-flow periods), rather than directly by precipitation. In any case, heavy precipitation and large snowmelt runoff would be expected to positively influence river flow rates, and thereby enhance erosion and possibly lead to an increase in landslide activity (Lebuis et al., 1983).

Case studies and discussions related to individual or a set of large landslide events in the glaciomarine clay typically note the rainfall or other anomalous weather leading up to the event as a possible trigger (e.g. Conlon, 1966; Eden et al., 1971; Tavenas et al., 1971; Eden, 1972; Karrow, 1972; Evans and Brooks, 1994; Evans et al., 1997; Hugenholtz and Lacelle, 2006). Similarly, rainfall and longterm precipitation averages are presented for two slides in sensitive clay deposits in Canada's northwestern British Columbia (Schwab et al., 2004; Geertsema et al., 2006) and in Norway (e.g. Hutchinson, 1961; Kenney and Drury, 1973). Hugenholtz and Lacelle (2006) compared the departure of annual precipitation from running averages against landslide frequency and found a significant positive correlation with the 10-yr average. Geertsema et al. (2006) showed that one large landslide in sensitive clay in northwestern British Columbia, Canada, occurred near the end of a 10 -yr period of warming temperatures and increased precipitation, although 


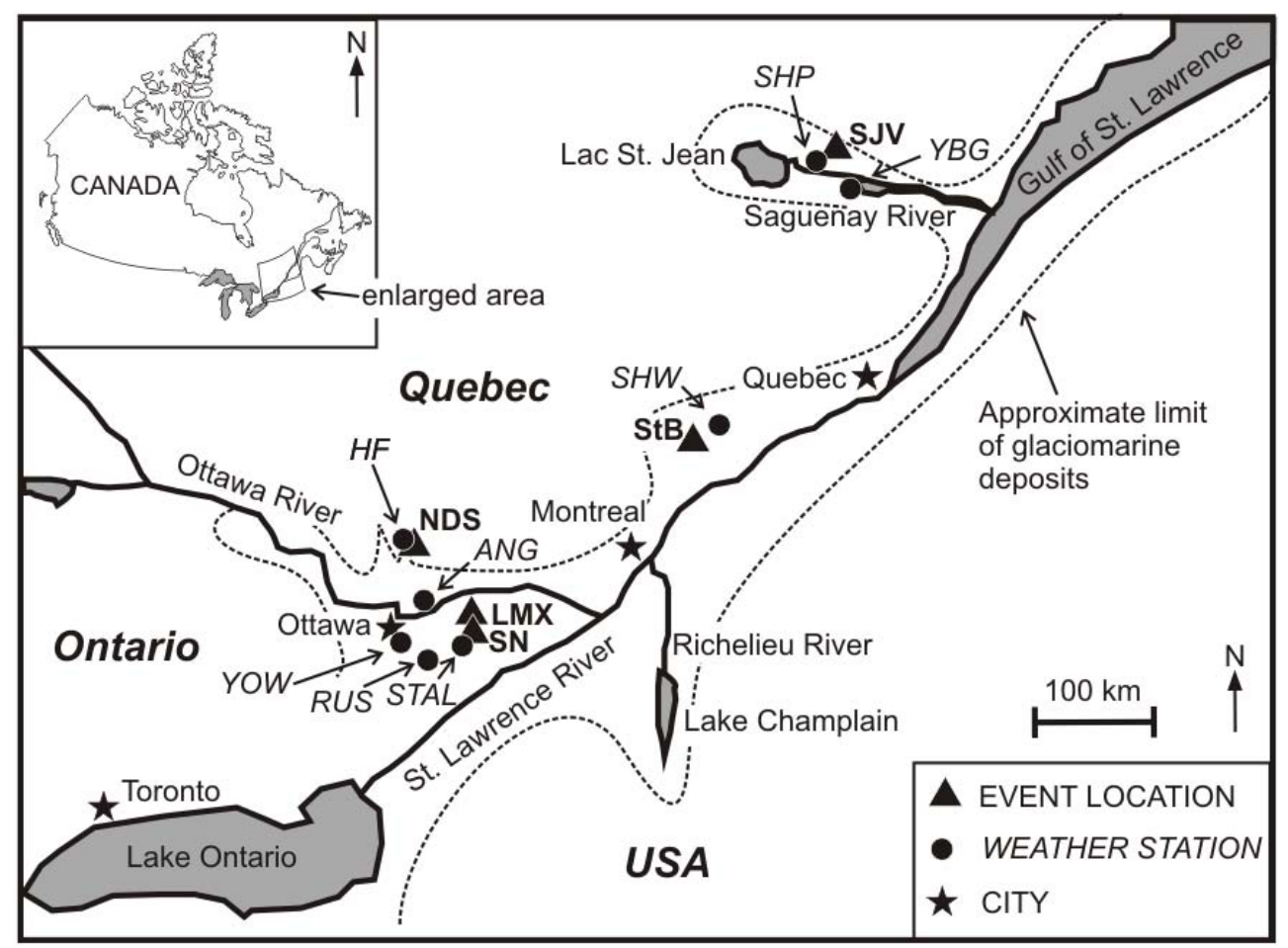

Fig. 1. Schematic map of study area showing major cities (star), landslide event locations (triangle) and Environment Canada weather stations (circle) used in this study. The dashed line indicates the approximate extent of the glaciomarine deposits, including sensitive clays prone to landsliding.

they did not specify the mechanism by which that interval of weather affected the stability of the soil.

We selected four of the landslide events for this study because they were very large (i.e. $>10^{6} \mathrm{~m}^{3}$ ), high profile, and had readily available, long-term, continuous daily weather data from a nearby weather station. We selected the fifth because it was recent (2010) and occurred approximately $22 \mathrm{~h}$ after a significant earthquake, which had an epicentre very close to the site of the slide; its primary trigger appears to be related the earthquake. Several other landslide events were considered, but were rejected because of the lack of reliable climate data, e.g. Toulnustouc QC in 1964 (Conlon, 1966), because they occurred outside the months during which almost $70 \%$ of landslides greater than 1 ha occurred (Lebuis et al., 1983), e.g. St. Barnabe, QC in 2005, because they are generally thought to have been triggered by human activities, e.g. Nicolet QC in 1955, Toulnustouc, 1964 (Crawford and Eden, 1963; Conlon, 1966), or because the case studies are not yet published (e.g. St. Jude QC in 2010). As such, this study contains neither a random nor an exhaustive sample of large landslides in sensitive soils in eastern Canada; however, we feel that our selections are justified given the available data and sparse records for many events. The locations of each landslide event are shown in Fig. 1.

\subsection{Saint Jean Vianney (SJV)}

On 4 May 1971, a large landslide occurred in sensitive glaciomarine clay at Saint Jean Vianney (SJV), Quebec, killing 31 people and destroying over 40 homes. Tavenas et al. (1971) provided the initial case study. The slide occurred approximately $2.5 \mathrm{~km}$ north of the Saguenay River along a tributary valley, approximately $10 \mathrm{~km}$ west of the city of Chicoutimi. Approximately $9 \times 10^{6} \mathrm{~m}^{3}$ of soil released, $7.5 \times 10^{6} \mathrm{~m}^{3}$ of which evacuated the crater and entered the Petit Bras River (Fig. 2a). Tavenas et al. (1971) reported that air temperatures had been rising throughout the month of April prior to the slide with above-freezing daily minimum temperatures beginning 21 April, which they suggest caused thawing of the surface soils. Based on rainfall records from a nearby weather station, they concluded that this landslide was triggered by the first heavy rain event after the ground thaw had occurred. The surface soils were ancient slide debris consisting of mixed sand and clay; the failure may have occurred within the ancient debris (Potvin et al., 2001) or within intact sensitive clay which rested directly on bedrock in this area (Tavenas et al., 1971; Fig. 2b). A smaller - although deep-seated - slide on 28 April 1971 may have been a partial trigger or cause of the larger event (Tavenas et al., 1971). 


\subsection{South Nation (SN)}

A large landslide occurred 16 May 1971, along the South Nation River (SN) near Casselman, Ontario, within the Champlain Sea basin (Fig. 1). Eden et al. (1971) presented a brief account of this event. The landslide involved approximately 28 ha of flat farmland, with a total volume of approximately $7 \times 10^{6} \mathrm{~m}^{3}$ (Fig. 2c). The crater was approximately $640 \mathrm{~m}$ wide, and extended $490 \mathrm{~m}$ inland. It occurred just before midnight during a heavy thunderstorm. Eden et al. (1971) noted that the winter of 1970-1971 was the snowiest on record, and that snowmelt had been gradual, to which they attributed extensive water infiltration and ground saturation. Local residents observed standing water in surrounding fields shortly before the landslide. The South Nation River had receded from its springtime peak shortly before the event, and groundwater was at surface in the slide area. Boreholes advanced nearby showed several metres of banded, silty fine sand overlying brown silty clay to a depth of approximately $10 \mathrm{~m}$ (Fig. 2d). Below $10 \mathrm{~m}$, the sensitive Champlain marine clay was grey, and included sand lenses. The Champlain clay rested on silty and sandy till with boulders, drifted over Paleozoic limestone bedrock.

\subsection{Lemieux (LMX)}

On 20 June 1993, another large landslide occurred along the South Nation River near Lemieux, ON, (LMX), only $4.5 \mathrm{~km}$ downstream from the 1971 South Nation slide (Fig. 1). Evans and Brooks (1994) reported on the event shortly after it occurred. Approximately $2.8 \times 10^{6} \mathrm{~m}^{3}$ of soil was involved, with a crater area of $17 \mathrm{ha}$, extending $680 \mathrm{~m}$ back from the riverbank (Fig. 2e). This landslide occurred in a known hazard area, and the scarp extended into the former town site of Lemieux, which had been abandoned in 1990. The slide crater was approximately $18 \mathrm{~m}$ deep, and over half of the material evacuated the crater and temporarily blocked the South Nation River. The local stratigraphy has up to $15 \mathrm{~m}$ of loose, brown silty sand and laminated silt and sand overlying the Champlain clay (Fig. 2f). Evans and Brooks (1994) reported that there was no obvious trigger for this landslide, although they did note very high late winter precipitation, including heavy snows in March and April, followed by a rapid melt and high water table.

\subsection{St. Boniface de Shawinigan (StB)}

On 21 April 1996 near St. Boniface de Shawinigan, QC, a very large landslide occurred, affecting both an electrical transmission corridor and a railway bridge (StB; Fig. 1). Evans et al. (1997) present a brief report on this slide, and Demers et al. (2000) provide more detail. The landslide encompassed greater than $7 \times 10^{6} \mathrm{~m}^{3}$ of soil, over an area exceeding 30 ha (Fig. 2g). Much of this material remained within the crater. Evans et al. (1997) report that the slide was triggered by heavy rains and snowmelt, although no further details are provided. Demers et al. (2000) describe a relatively consistent stratigraphy throughout the site: approximately $10 \mathrm{~m}$ of massive to stratified sand over $5 \mathrm{~m}$ of stratified clayey silt (Fig. 2h). Below $15 \mathrm{~m}$ depth was massive clayey silt to $28 \mathrm{~m}$, and massive clay and silt to $60 \mathrm{~m}$. Rhythmic fluctuations in mechanical properties probably related to grain size are present in both "massive" units (Demers et al., 2000).

\subsection{Notre-Dame-De-La-Sallette (NDS)}

On 23 June 2010, a moment magnitude 5.0 earthquake occurred near Val-Des-Bois, QC; approximately $22 \mathrm{~h}$ later (24 June 2010) a large landslide released at a site located $14 \mathrm{~km}$ southwest of the epicentre, along a small creek near NotreDame-De-La-Salette (NDS; Fig. 1). Perret et al. (2011) provide the only available summary: the crater was approximately $150 \mathrm{~m}$ wide by $420 \mathrm{~m}$ long (retrogression distance), and had at least three sub-horizontal benches or steps within it, apparently representing discrete failure surfaces (Fig. 2i, j). The crater was evacuated almost completely. The preliminary assessment of this slide is that the earthquake triggered a slip-type failure along the riverbank, which developed into a delayed retrogressive failure, finally releasing almost a full day after the earthquake. Progressive development of a failure surface (e.g. Quinn et al., 2011b; Locat et al., 2011) is one other possible explanation for the delay between the earthquake and landslide. Only one other landslide is known to have occurred in southern Quebec in the days following the earthquake. Rainfall or precipitation is not noted as a trigger for these events, making the NDS slide particularly interesting for the current study.

\subsection{Common features}

The first four landslide events summarized here have several features in common, aside from the basic physical and spatial ones. First, each occurred during the spring months of April, May, or June, when over $70 \%$ of all the large landslides in Quebec have occurred (Lebuis et al., 1983). Second, in each case the most detailed reports cite heavy precipitation and/or snowmelt as the trigger of the landslide, but no characteristic length scale of the precipitation events are discussed, and the snowfall and melt or precipitation amounts have not been placed in the long-term context. For example, "heavy" rains are expected to occur during the spring months each year in most parts of eastern Canada, but large, catastrophic landslides are not triggered at the same frequency. The fifth landslide we analyze occurred under similar conditions to the other four, except in this case no meteorological trigger has been identified previously, at least in part due to the temporal relationship to a significant earthquake. In this paper, we attempt to relate the occurrence of these five large but rare landslide events with coincident potential 

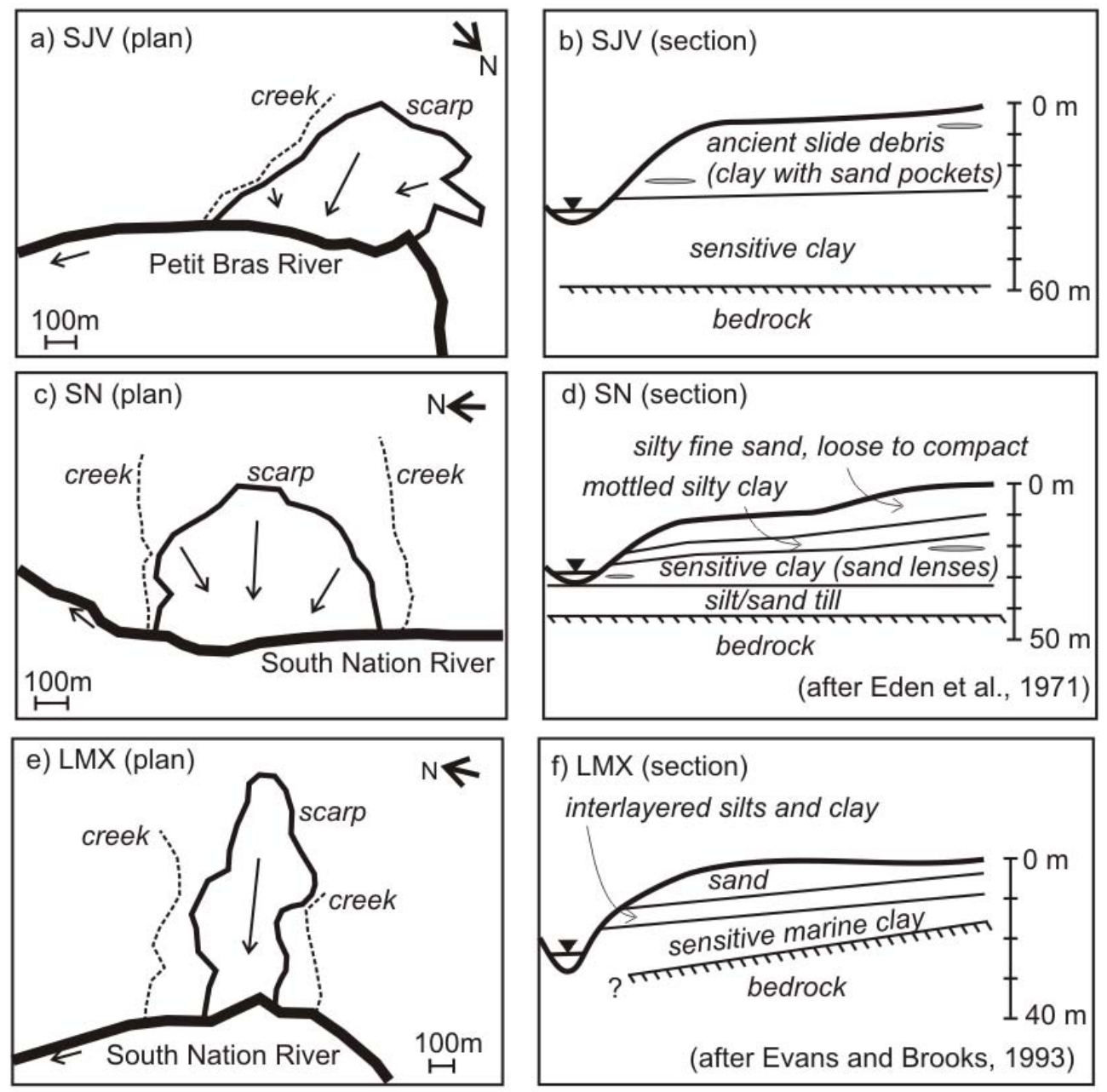

Fig. 2. Schematic of landslide areas and soil profiles for each site: (a, b) St. Jean Vianney (SJV); (c, d) South Nation (SN); (e, f) Lemieux (LMX).

meteorological triggers. This is not intended to specify some return interval or provide a risk analysis for a given site, or even to presume some causative mechanism. We simply identify in more detail those scales and types of weather that are at minimum related temporally to large landslides in sensitive clay soils. We apply those insights to discuss some possible mechanical influence of the trigger on the stability of the soil.

\section{Methods and data}

Weather and climate data for each landslide event comes from the Environment Canada (EC) National Climate Data and Information Archive (available on-line). We selected representative weather stations for each landslide based on proximity and expected similarity to the weather at the landslide site, and the scope and temporal extent of the record. Table 1 summarizes the landslide and weather sites, and weather data records included in this study.

\subsection{SJV}

Weather data for the analysis of the SJV landslide is available from Shipshaw (SHP, EC ID: 7068160), which is located $2.5 \mathrm{~km}$ south of the landslide site (Fig. 1; Table 1). Precipitation data there were available from 1943-1993, with snow height recorded reliably from 1981-1993. We assume the record at SHP is applicable directly to the SJV site and use it to calculate antecedent precipitation and rankings. As there are no snow height records for the winter of 1970 1971, we tested the applicability of snow height data from a nearby station at Bagotville Airport (YBG, EC ID: 7060400). The YBG station is located approximately $23 \mathrm{~km}$ southeast of the SJV landslide. Precipitation and temperature records for YBG were available from 1942-1944 and 1946-2010, while snow heights were collected from 1956-2010. We used the Spearman Rank Correlation to compare the cumulative precipitation between the two sites for two intervals each winter where both stations had data. There were $40 \mathrm{yr}$ with 

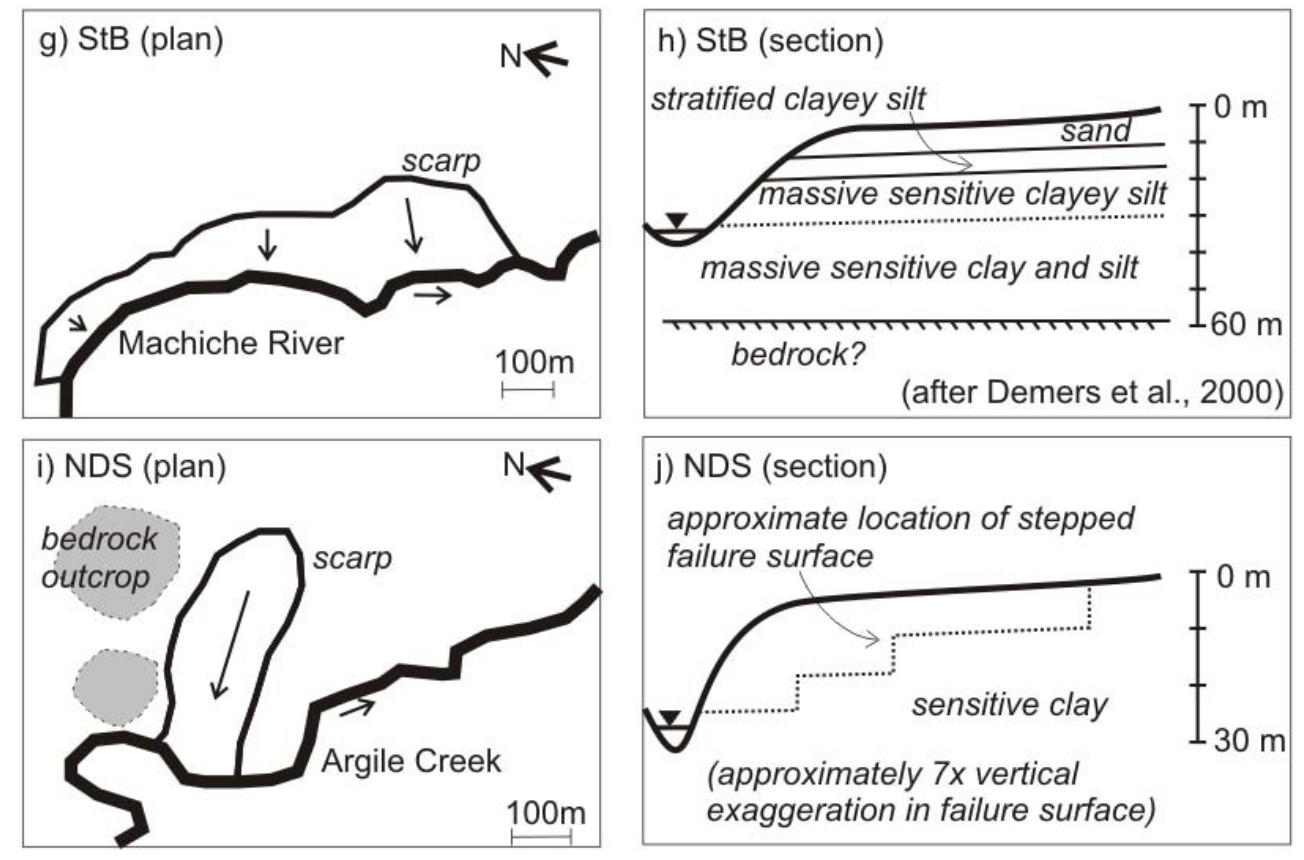

Fig. 2. (continued): (g, h) St. Boniface (StB); (i, j) Notre-Dame-De-La-Salette (NDS).

Table 1. Summary of landslide events included in this study and the Environment Canada (EC) weather station and ranges used for meteorological data. The distance and direction from each landslide site to its corresponding weather station is indicated.

\begin{tabular}{|c|c|c|c|c|c|}
\hline Event & Date & EC Station name & Distance to station & $\begin{array}{l}\text { Meteorological } \\
\text { records }\end{array}$ & $\begin{array}{l}\text { Snow height } \\
\text { records }\end{array}$ \\
\hline \multirow[t]{2}{*}{$\begin{array}{l}\text { St. Jean } \\
\text { de Vianney (SJV) }\end{array}$} & \multirow[t]{2}{*}{4 May 1971} & $\begin{array}{l}\text { Bagotville Airport } \\
\text { (YBG) }\end{array}$ & $23 \mathrm{~km} \mathrm{SE}$ & $\begin{array}{l}1942-1944, \\
1946-2010\end{array}$ & 1956-2010 \\
\hline & & Shipshaw (SHP) & $2.5 \mathrm{~km} \mathrm{~S}$ & 1943-1993 & 1981-1993 \\
\hline \multirow[t]{2}{*}{ South Nation (SN) } & \multirow[t]{2}{*}{16 May 1971} & $\begin{array}{l}\text { Ottawa MacDonald- } \\
\text { Cartier } \\
\text { Airport (YOW) }\end{array}$ & $45 \mathrm{~km} \mathrm{~W}$ & 1953-2010 & 1955-2010 \\
\hline & & St. Albert (STAL) & $17 \mathrm{~km} \mathrm{SSW}$ & 1986-2010 & $\sim$ \\
\hline \multirow[t]{3}{*}{ Lemieux (LMX) } & \multirow[t]{3}{*}{20 June 1993} & $\begin{array}{l}\text { Ottawa MacDonald- } \\
\text { Cartier } \\
\text { Airport (YOW) }\end{array}$ & $48 \mathrm{~km} \mathrm{~W}$ & 1953-2010 & 1955-2010 \\
\hline & & Russell (RUS) & $29 \mathrm{~km} \mathrm{SW}$ & $\begin{array}{l}\text { 1954-1962, } \\
1975-2010\end{array}$ & 1980-2010 \\
\hline & & St. Albert (STAL) & $17 \mathrm{~km} \mathrm{SSW}$ & 1986-2010 & $\sim$ \\
\hline St. Boniface (StB) & 21 April 1996 & Shawinigan (SHW) & $13 \mathrm{~km} \mathrm{NE}$ & $\begin{array}{l}1902-1996, \\
1998-2010^{*}\end{array}$ & 1980-1996 \\
\hline \multirow{2}{*}{$\begin{array}{l}\text { Notre Dame De } \\
\text { La Sallette (NDS) }\end{array}$} & 24 June 2010 & Angers (ANG) & $30 \mathrm{~km} \mathrm{~S}$ & 1962-2011 & 1980-2011 \\
\hline & & High Falls (HF) & $7 \mathrm{~km} \mathrm{NW}$ & $\begin{array}{l}1933-1972 \\
1999-2011\end{array}$ & $\sim$ \\
\hline
\end{tabular}

* no precipitation data during winter

overlapping data available for the intervals 1 November to 30 April ("long winter") and the 15 November to 15 April ("short winter") periods; correlations were significant with better than $99 \%$ confidence (i.e. $p<0.01$ ), with coefficients of 0.54 and 0.58 , respectively. A lagged cross-correlation analysis showed strong correlation at zero lag and only weak correlations at lags greater or less than zero days, which suggests that the winter snowpack would evolve similarly, even 
if the precipitation amounts varied. Within each station's record, the winter of 1971 ranks in the 88th and 79th percentiles for the long and short winters, respectively, at SHP, but in the 54th and 31st percentile at YBG for the same intervals. Given these results, we tentatively include the snow height records from YBG, and focus on the evolution of the snowpack through the winter rather than the absolute value or ranking of the data.

\subsection{SN and LMX}

The closest weather station with an appropriate interval, duration, and detail of records for the SN landslide is at the MacDonald-Cartier International Airport in Ottawa (YOW, EC ID: 6106000). The YOW station is located approximately $45 \mathrm{~km}$ west of the SN site (Fig. 1; Table 1). It has precipitation and temperature records for the period 1953-2010, with snow height records from 1955-2010. For the nearby LMX landslide, records are available from YOW as well as a closer station at Russell (RUS, EC ID: 6107247). The YOW station is located $48 \mathrm{~km}$ west of the LMX site, while the RUS station is $29 \mathrm{~km}$ southwest (Fig. 1; Table 1). Precipitation data are available for RUS from 1954-1962 and 1975-2010. Snow heights were recorded from 1980-2010. A third station at St. Albert (STAL; EC ID: 6107276) is located approximately $13 \mathrm{~km}$ south of SN and $17 \mathrm{~km}$ south-southwest of LMX; however, precipitation was only recorded over the interval 1986-2006, and snow height was never recorded. Nonetheless, if we assume that STAL is the best-situated station for the SN and LMX sites, we may test the applicability of the YOW and RUS data to the landslide sites and intervals. Table 2 shows the lagged cross-correlation coefficients for these comparisons. We found mostly strong, positive correlations above 0.70 for zero lag (days). The RUS site showed a weak correlation with a lag of positive one day, while YOW had a weak correlation with a lag of negative one day. Furthermore, we compared the YOW and RUS stations for the same interval and found a strong, positive correlation, and a second, weaker correlation, with YOW lagged negative one day (Table 2). We interpret these results to suggest that while not a perfect match, the daily precipitation patterns between YOW, RUS, and STAL (the most proximal to SN and LMX landslide sites) are sufficiently similar to permit using them interchangeably. This matches our expectations, since these locations are at a similar elevation with no interfering topography. Local, convective thunderstorms or squalls may represent the main difference between the weather sites and the landslide sites, i.e. locally heavy precipitation may occur at only one site.

\subsection{StB}

The weather record for the StB slide is from the nearby Shawinigan station (SHW, EC ID: 7018000) located $13 \mathrm{~km}$ northeast of the slide site (Fig. 1; Table 1). Weather data are available from the intervals 1902-1996 and 1998-2010, although wintertime precipitation was not recorded during the latter interval. Snow height data were collected from 19801996.

\subsection{NDS}

Weather data for the NDS landslide comes mainly from a station at the High Falls dam (HF; EC ID: 7033120), which is $7 \mathrm{~km}$ northwest of the landslide site. Precipitation records are available for the periods 1933-1972 and 1999-2011; however, snow heights were never recorded. The nearest station with reliable snow height data is $30 \mathrm{~km}$ south at Angers (ANG; EC ID: 7030170). There, precipitation and snow height were recorded between 1980 and 2011. For the interval with overlapping precipitation records (1962-1972 and 1989-2011), we test whether it is acceptable to utilize snow height records from ANG for the landslide at NDS by comparing daily precipitation using a lagged cross-correlation. Table 2 shows a moderate correlation of 0.61 at zero days lag, and a weaker correlation of 0.23 with $\mathrm{HF}$ at negative 1 day lag. As with the SJV event, here we used the Spearman Rank Correlation to compare the cumulative precipitation between the two sites for two intervals in each overlapping winter. There were only $11 \mathrm{yr}$ with complete (fewer than five missing data per year) records available for the intervals 1 November to 30 April ("long winter") and the 15 November to 15 April ("short winter"). We found correlations of $0.69(p=0.018)$ and $0.52(p=0.09)$ for those intervals, respectively. Given these results, we tentatively accept that snow height records from ANG may be applied to the NDS site when considering longer-term patterns, with the caveat that divergence is possible in any given year. For example, 2010 was a very high-ranking winter in terms of precipitation at HF but not at ANG, although the absolute differences were not large.

\subsection{Analytical methods}

We used daily weather records from each weather station for this study. For each available day in the record for each site, we selected the daily precipitation (rain and snow water equivalent; $\mathrm{mm})$, daily rain $(\mathrm{mm})$, daily snowfall $(\mathrm{cm})$, and where available the total height of snow on the ground. In addition, we collected daily minimum, mean, and maximum temperatures $\left({ }^{\circ} \mathrm{C}\right)$. Then we compiled a chronological dataset for the complete record period, with one value for each variable for each day. For each day, antecedent precipitation was calculated as the cumulative precipitation for one, two, three, seven, $14,21,28,56,112$, and 365 days, beginning at the end of each day (i.e. the one-day precipitation was the value from 
Table 2. Lagged cross-correlations between stations as indicated, with the time series for STN2 "lagged" ahead (positive) and behind (negative) of STN1. Correlations that are greater than twice their standard error are in bold.

\begin{tabular}{llllll}
\hline STN2 Lag (days) & \multicolumn{5}{c}{ Cross-Correlation Coefficient $(\mathrm{STN} 1 / \mathrm{STN} 2)$} \\
& SHP/YBG & STAL/RUS & STAL/YOW & RUS/YOW & ANG/HF \\
\hline-5 & $\mathbf{0 . 0 2}$ & 0.00 & 0.00 & 0.00 & -0.01 \\
-4 & $\mathbf{0 . 0 2}$ & -0.01 & 0.00 & 0.01 & -0.01 \\
-3 & 0.00 & 0.00 & 0.00 & -0.01 & -0.02 \\
-2 & -0.00 & 0.00 & -0.02 & -0.01 & $-\mathbf{0 . 0 2}$ \\
-1 & $\mathbf{0 . 2 3}$ & $\mathbf{0 . 0 7}$ & $\mathbf{0 . 2 3}$ & $\mathbf{0 . 3 3}$ & $\mathbf{0 . 2 4}$ \\
0 & $\mathbf{0 . 6 9}$ & $\mathbf{0 . 8 2}$ & $\mathbf{0 . 7 3}$ & $\mathbf{0 . 7 0}$ & $\mathbf{0 . 6 1}$ \\
1 & $\mathbf{0 . 0 9}$ & $\mathbf{0 . 1 9}$ & $\mathbf{0 . 0 3}$ & 0.01 & $\mathbf{0 . 0 3}$ \\
2 & 0.00 & 0.00 & -0.02 & 0.00 & -0.01 \\
3 & 0.01 & 0.01 & 0.01 & 0.00 & -0.01 \\
4 & 0.00 & 0.01 & 0.00 & 0.00 & -0.01 \\
5 & $\mathbf{0 . 0 2}$ & 0.00 & 0.00 & -0.01 & 0.01 \\
\hline
\end{tabular}

that day). These arbitrary ranges were chosen to roughly correspond to short-term (i.e. one to three days) and longer-term (i.e. seven to 28 days) stormy weather periods, and seasonal or annual weather trends (i.e. 56 to 365 days). We ranked the antecedent precipitation values calculated for the day of each landslide within the entire record. We expect that if heavy precipitation triggered a landslide event, one or more of the antecedent precipitation variables will be highly ranked i.e. the landslide would occur during the wettest periods in the record. Closely spaced antecedent intervals are expected to be autocorrelated, although this does not necessarily reduce the significance of multiple high-ranking intervals for a given landslide event. To improve the resolution of the antecedent precipitation variables, we also ranked antecedent precipitation for each landslide event within a subset of the entire record that included only days from April, May, and June of each year. Particularly for the shorter intervals, this would exclude from the ranking many stormy periods not expected to trigger landslides directly, such as major winter snowstorms.

We assumed that any days without data in the Environment Canada records were missing at random and could therefore be omitted from the analysis. This assumption is justified if there was no systematic cause of "missingness" in the data that was related to the observations, e.g. heavy rain or low temperatures consistently caused the failure of recording instruments. However, the effect is to reduce progressively the size of the dataset for increasing antecedent precipitation ranges, as the likelihood of encountering a missing value increases with the duration of the range. While the ranking of landslide days in the total record remains valid despite some missing daily data, we also chose to omit from further analysis any calculated antecedent precipitation values for a given landslide day that contained a missing or invalid precipitation datum anywhere in the interval. Again, this is justified as long as each missing value was the result of a random process.
Eden et al. (1971) and Evans and Brooks (1994) noted high winter snowfall as a partial cause or contributing trigger of the SN and LMX landslides, respectively. The antecedent precipitation variables may not capture this factor, so we tested the relationship between landslide occurrence and the winter season precipitation by calculating the total precipitation recorded for the interval 15 November to 15 April (i.e. short winter) and 1 November to 30 April (i.e. long winter). These winter intervals are arbitrary, but cursory inspection of available snowpack height records indicate that they capture the period of most years where snowfall is possible. We analyze only the total precipitation $(\mathrm{mm})$, since the height of any given snowfall is a derivative measure of the density of the snow and the total quantity of water-equivalent it contains. Only the latter is expected to affect the mechanics of the soil and landslide activity. For the winter precipitation variable, we compared the value for the year of the landslide to all other available years for each site. We expect that landslides occurred in years with heavy winter precipitation, which would result in additional volumes of surface water available for infiltration and runoff in spring. This may promote saturation and destabilizing of soils. We also plotted the evolution of the snow height throughout each winter season preceding the landslide. This is a convenient method of qualitatively assessing the weather patterns and potential impact winter weather on spring landslides.

\section{Results}

Figures 3 and 4 show the cumulative precipitation value for each landslide day at each antecedent interval, and show the distribution of values for the entire dataset (Fig. 3) and the A-M-J subset (Fig. 4). 


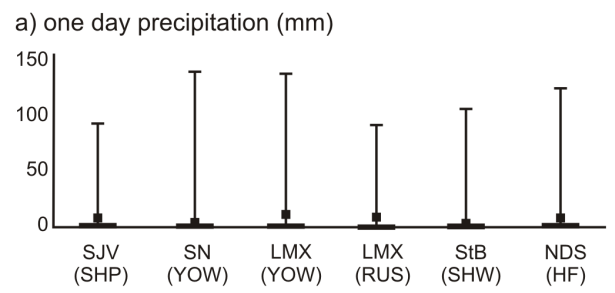

c) three day precipitation $(\mathrm{mm})$

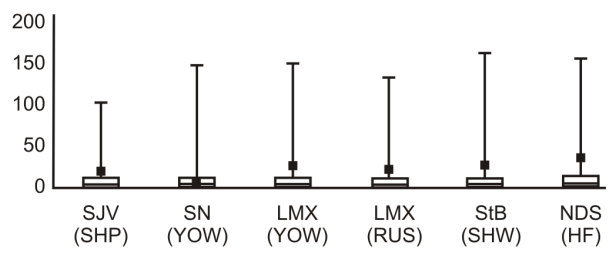

e) 14 day precipitation $(\mathrm{mm})$

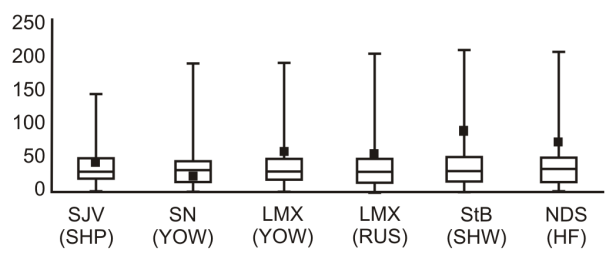

g) 28 day precipitation $(\mathrm{mm})$

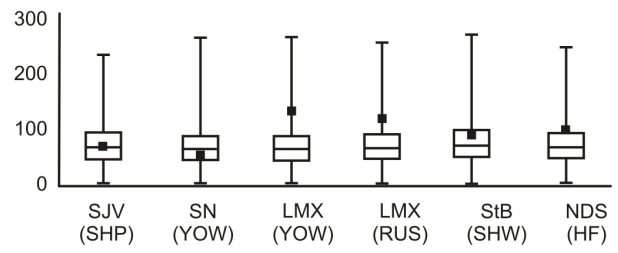

i) 112 day precipitation $(\mathrm{mm})$

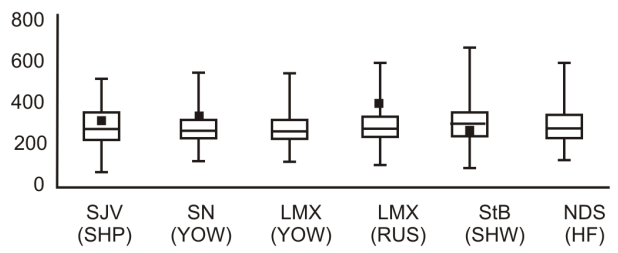

b) two day precipitation ( $\mathrm{mm}$ )

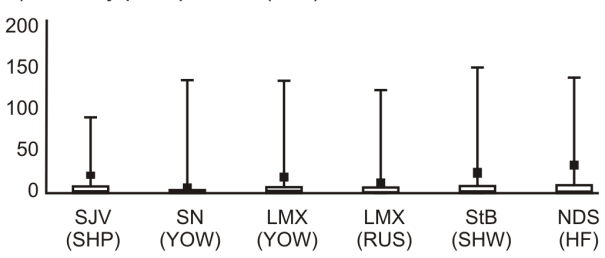

d) seven day precipitation ( $\mathrm{mm}$ )

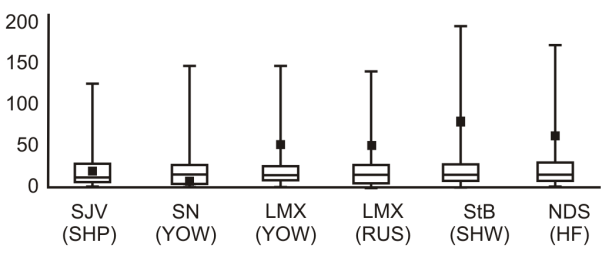

f) 21 day precipitation $(\mathrm{mm})$

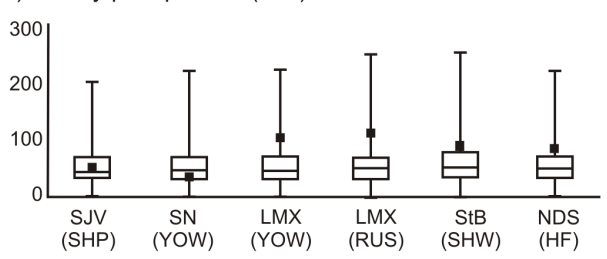

h) 56 day precipitation $(\mathrm{mm})$

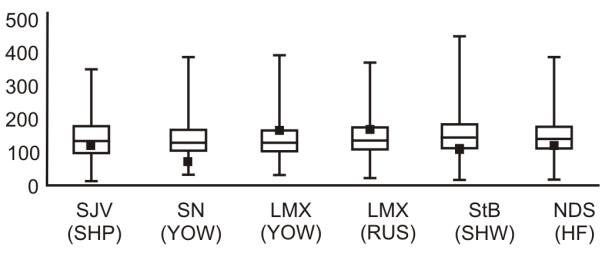

j) 365 day precipitation ( $\mathrm{mm}$ )

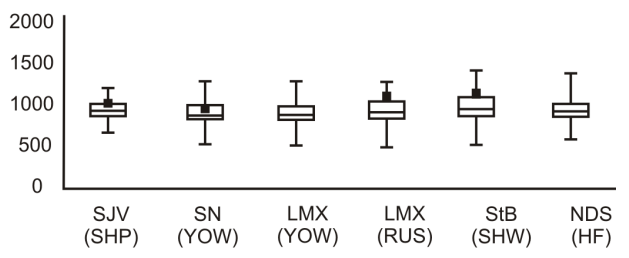

Fig. 3. Box and whisker plots comparing antecedent precipitation for each site (and weather station), at each interval. The "whiskers" indicate the range, the box boundaries mark the upper and lower quartiles, and the bar marks the median value. The filled square is the value for the landslide day at each site.

\subsection{SJV}

The two-day precipitation for the SJV landslide, recorded at SHP, ranked at $93.5 \%$ in the record, with $19 \mathrm{~mm}$ of precipitation (Fig. 3b). In the A-M-J subset, the two-day precipitation ranked $93.7 \%$ (Fig. 4b). Furthermore, the 112-day precipitation ranked at $94.9 \%$ within the A-M-J subset (Fig. 4i). The one-day and three-day were highly ranked in the complete and A-M-J subsets, both near $90 \%$ rank (Figs. 3a, c, $4 \mathrm{a}, \mathrm{c})$. The one-year antecedent precipitation was also ranked above $80 \%$ in both (Figs. 3j, 4j). Still, more than 200 days in April, May, and June in the record for the SHP station had higher two- and 112-day antecedent precipitation at SHP, but no large landslide event.

\subsection{SN and LMX}

Figures 3 and 4 shows mostly low-ranking antecedent precipitation values within the entire record from the YOW station for the SN landslide. No interval ranked higher than $83 \%$ in a record of over 20000 days. Ranks for all intervals were low in A-M-J subset as well, except for the 112-day precipitation at $95.8 \%$ (Fig. 4i). In this case, 226 days in the A-M-J subset $(n=5147)$ had higher 112-day precipitation. The intervals 

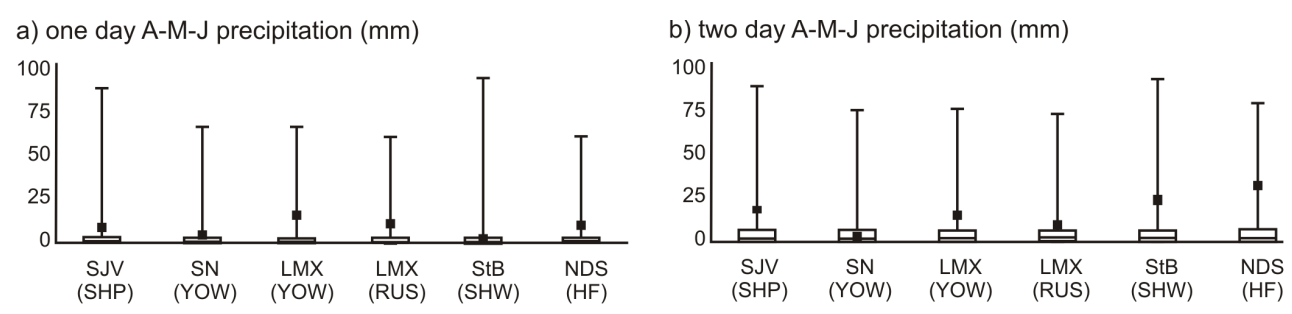

c) three day A-M-J precipitation ( $\mathrm{mm}$ )
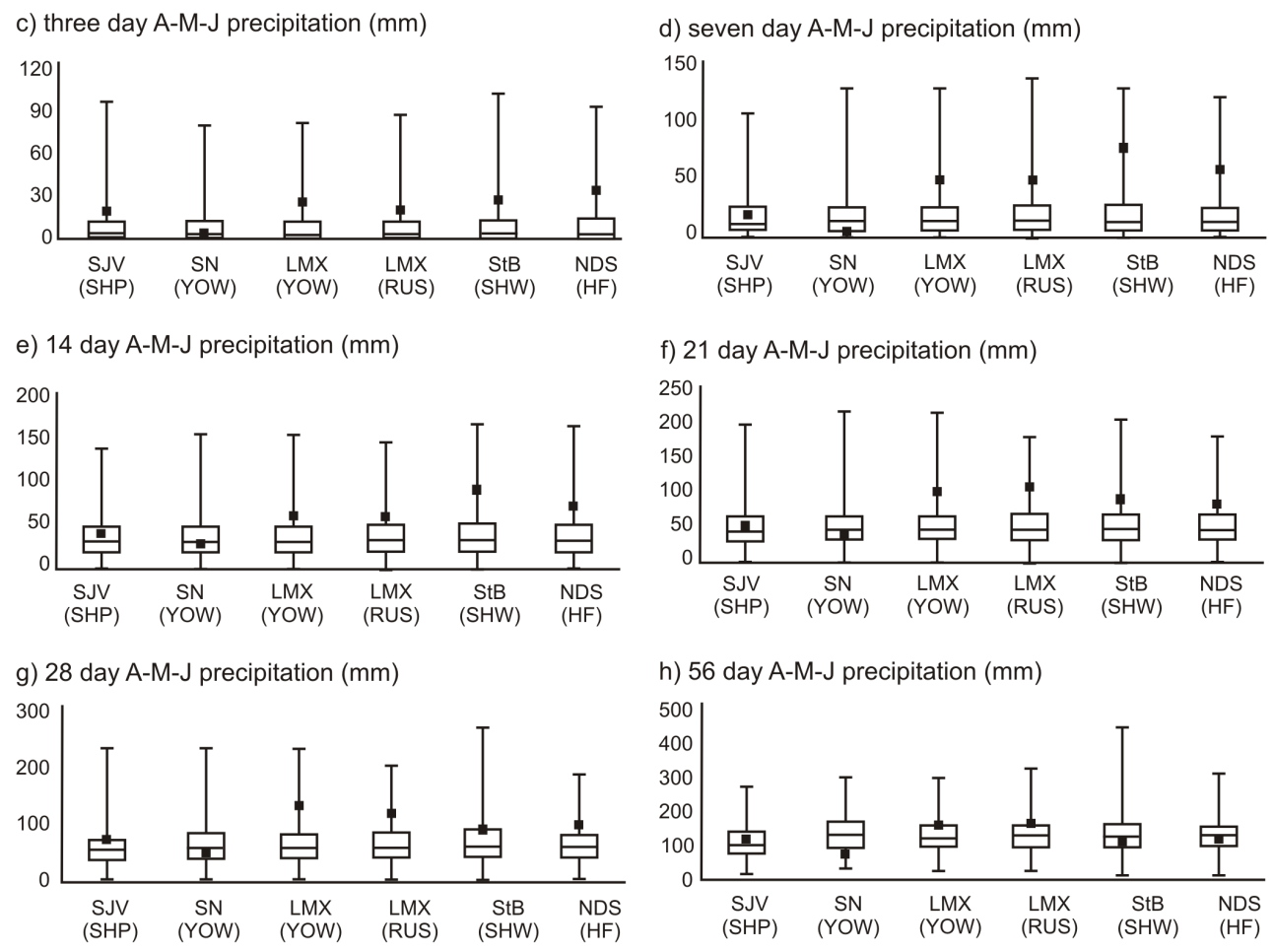

i) 112 day A-M-J precipitation ( $\mathrm{mm}$ )
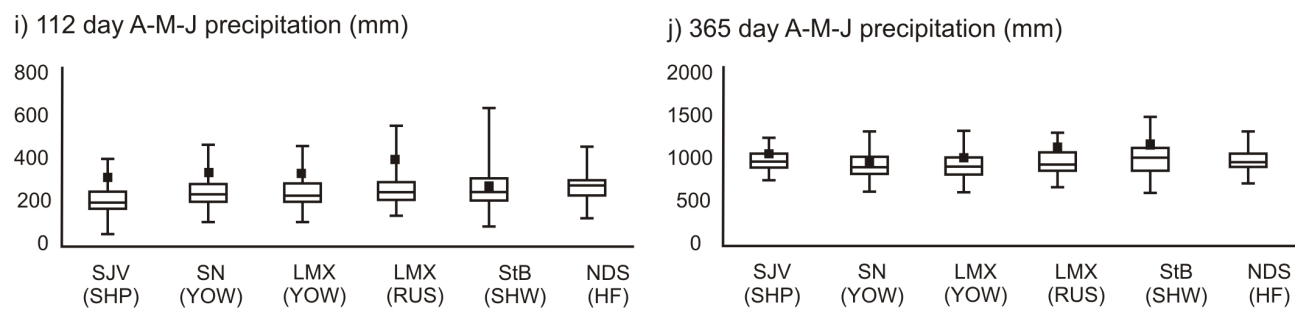

Fig. 4. Box and whisker plots comparing antecedent precipitation for days in April, May, and June (A-M-J), for each site (and weather station), at each interval. The "whiskers" indicate the range, the box boundaries mark the upper and lower quartiles, and the bar marks the median value. The filled square is the value for the landslide day at each site.

from seven to 56-days each ranked below $50 \%$ of the other days in the record, for both the complete dataset and the AM-J subset. At $6.4 \%$ and $9 \%$ the 56-day antecedent interval preceding the SN slide were among the driest on record.

In the YOW record, the one, two, three, seven, 21 and 28 day antecedent precipitation for the day of the LMX landslide exceeded the $90 \%$ rank within the complete record ( $n>20000$, Fig. 3). The highest was the one-day precipitation of $15.8 \mathrm{~mm}$ (96\% rank; Fig. 3a), with the seven and 28day values also exceeding $95 \%$ rank (Fig. 3d, h). For these, at least 840 other days in the record had greater precipita- tion. For the A-M-J subset, the 28-day precipitation was the highest ranked (97.2\%; Fig. 4g), with most other intervals similarly ranked in the A-M-J and the entire record. Unfortunately, some data are missing in the record for YOW during the 56-, 112- and 365-day antecedent intervals, which means that we could not calculate those values. We were able to calculate all intervals for the RUS weather station, and they show a similar pattern to those at the YOW station. The highest-ranking interval was the 21 -day, at $95 \%$ (Fig. 3f), with the one, seven, 28- and 112-day intervals all exceeding $90 \%$ of days in the record $(n>11000$; Fig. 3a, d, 
Table 3. Comparison of antecedent precipitation (AP) for the day of the LMX event calculated from STAL, RUS, and YOW stations.

\begin{tabular}{llll}
\hline & \multicolumn{3}{c}{ AP $(\mathrm{mm})$} \\
AP (days) & STAL & RUS & YOW \\
\hline 1 & 10.8 & 10.6 & 15.8 \\
2 & 10.8 & 10.6 & 16 \\
3 & 17.4 & 19 & 24.6 \\
7 & 51.2 & 48.6 & 48.8 \\
14 & 57.2 & 56 & 58 \\
21 & 100.4 & 110.4 & 100.8 \\
28 & 122 & 118.6 & 132.8 \\
56 & 165.4 & 172.6 & $\sim$ \\
112 & 407.8 & 398 & $\sim$ \\
365 & 1179.7 & 1127.5 & $\sim$ \\
\hline
\end{tabular}

g, i). Within the A-M-J subset, the highest-ranking interval was 365 -days at $94.2 \%$ (Fig. 4 j). The 21-day interval was at $91.5 \%$ rank (Fig. 4f). This means that approximately 160 and 324 days in the A-M-J subset had higher-ranking precipitation for the 21- and 365-day intervals, respectively. To compare further the results from the three weather stations with data for the LMX landslide, we plotted the absolute value of precipitation for each antecedent interval in Table 3. This shows excellent agreement between RUS and STAL for all intervals, and YOW for intervals longer than three days, although the one- and two-day values are within $5 \mathrm{~mm}$.

\subsection{StB}

Inspection of Fig. 3d shows that the seven-day interval preceding the StB landslide ranked $98.9 \%$ out of 34445 days in the SHW record. That is the highest ranking of any interval tested in this study. The one, three, and 14-day intervals also ranked greater than $90 \%$, while the 21- and 365-day intervals ranked above $85 \%$ (Fig. 3). The intervals ranked similarly in the A-M-J subset, with the highest being seven days at $98.8 \%$ (Fig. 4d). Note that $82.4 \mathrm{~mm}$ of precipitation fell in the eight days preceding the StB landslide, which would rank above $99 \%$ in the A-M-J subset; however, this means that $1 \%$ or approximately 90 days in the record had this greaterranking seven- or eight-day precipitation but no landslide.

\subsection{NDS}

Figures 3 and 4 show that the period leading up to the NDS slide was relatively wet compared to the entire record. All of the intervals up to 14 days for the complete and spring records at HF (greater than 18000 and greater than 4200 days, respectively) were ranked above $90 \%$ (Fig. 3), with the highest being the two-day intervals at approximately $98 \%$ (Fig. 3b). This means that approximately 362 days in the complete record and less than 90 spring days had wetter two-day antecedent precipitation. Note that the two-day precipitation includes values recorded at the end of the day of the landslide and the day of the earthquake, meaning that much of the $32 \mathrm{~mm}$ of precipitation recorded at HF could have fallen in the time between the earthquake and the landslide. Both the 21- and 28-day intervals were also highly ranked at approximately $80 \%$ (Fig. 3f, g), although at 56-days the precipitation was only ranked $33 \%$ and $44 \%$ for the complete and spring records, respectively (Figs. $3 \mathrm{~h}, 4 \mathrm{~h}$ ). Missing data for the longer intervals at HF (112- and 365-day) meant that it was not possible to calculate those rankings.

\subsection{Winter precipitation}

Tables 4 and 5 show the cumulative precipitation $(\mathrm{mm})$ for the short (Table 4) and long (Table 5) winter intervals preceding each landslide. Those values are compared to all of the other years in the record. Figure 5a-d shows the evolution (accumulation and ablation) of the winter season snowpack for each landslide year, compared to the average and maximum recorded at the station.

Short winter precipitation at the YBG station preceding the SJV landslide ranked 29 out of $62 \mathrm{yr}$ in the record (54\%; Table 4), while at SHP station approximately $75 \mathrm{~mm}$ more precipitation fell, making 1970-1971 the sixth wettest short winter in the $44 \mathrm{yr}$ record ( $88.3 \%$ rank). At both stations, precipitation over the longer winter interval ranked lower than the short, at $31.1 \%$ and $79 \%$ for the YBG and SHP stations, respectively (Table 5). Snow height records were not available for the winter 1970-1971 at the SHP station; however, Fig. 5a shows the snow heights from the YBG station. Snow heights were mostly below average in 1970-1971 until midFebruary, after which they were mostly near average levels. Snow height reached zero on 25 April 1971.

The winter 1970-1971 preceding the landslide at SN was the second wettest in the 55 year record for the short-winter interval (98.1\%; Table 4), and the third wettest for the long winter (96.2\% rank; Table 5). For both the long and short intervals, the winter of 1970-1971 had the most precipitation ever recorded at the time, until it was exceeded in 2008 (short winter) and 1984 (long winter). In addition, the winter of 1970-1971 had the most snowfall ever recorded at the YOW station (1953-2010), and much of the year had the highest snow height on record. Inspection of Fig. 5b shows that despite being a record season for snowfall, almost no snow accumulated on the ground until after 1 December 1970. The height of snow on the ground increased rapidly, reaching a record high level by late December, and remaining there for much of the remainder of the winter, particularly during the late season after 1 April 1971. Snow height reached zero on 22 April 1971.

The winter of 1992-1993 is missing data at the YOW station, meaning that the winter precipitation values cannot be calculated accurately. For the RUS station, Table 4 shows that the year of the LMX landslide was the seventh wettest short winter in the record of $34 \mathrm{yr}$, while the long winter was the second wettest (96.9\%; Table 5), exceeded only by 2008 . 

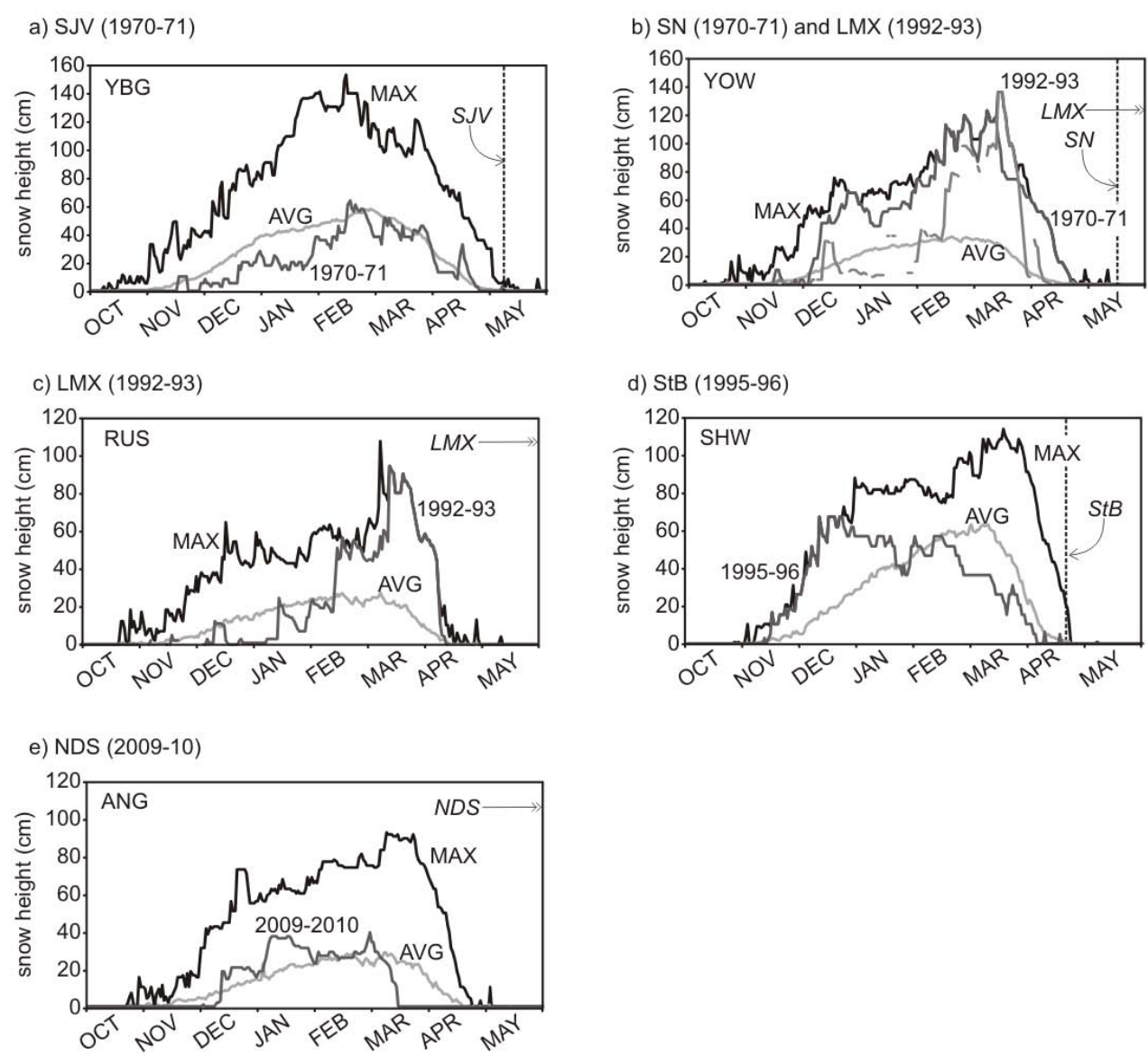

Fig. 5. Daily snow height $(\mathrm{cm})$ evolution for the winter preceding each landslide, compared with the maximum and average for the station at each landslide site.

Table 4. "Short winter" (15 November to 15 April) precipitation $(\mathrm{mm})$ preceding each landslide, showing rank and percent rank (\% rank) within entire record (valid $\mathrm{n}$ ) for the corresponding station.

\begin{tabular}{llllll}
\hline Event & Site & mm & \% rank & valid n & Rank \\
\hline SJV & YBG & 306.9 & 54 & 62 & 29 \\
& SHP & 380.2 & 88.3 & 44 & 6 \\
SN & YOW & 449.5 & 98.1 & 55 & 2 \\
LMX & YOW & $\sim$ & $\sim$ & $\sim$ & $\sim$ \\
& RUS & 404 & 82.8 & 36 & 7 \\
StB & SHW & 328.1 & 31.5 & 77 & 53 \\
NDS & ANG & 311 & 21.4 & 29 & 23 \\
& HF & $\sim$ & $\sim$ & $\sim$ & $\sim$ \\
\hline
\end{tabular}

There are no data in this record for the years 1963 to 1974 (inclusive), and the very wet winter of 1970-1971 is therefore not available for comparison. Available snow height data preceding the LMX slide are plotted for the YOW station in Fig. $5 b$ despite the missing data. The record shows mostly average or below average snow levels for the early part of
Table 5. "Long winter" (1 November to 30 April) precipitation $(\mathrm{mm})$ preceding each landslide, showing rank and percent rank (\% rank) within entire record (valid $\mathrm{n}$ ) for the corresponding station.

\begin{tabular}{llllll}
\hline Event & Site & $\mathrm{mm}$ & \% rank & valid $\mathrm{n}$ & Rank \\
\hline SJV & YBG & 345.6 & 31.1 & 62 & 43 \\
& SHP & 429.3 & 79 & 44 & 10 \\
SN & YOW & 515.50 & 96.2 & 55 & 3 \\
LMX & YOW & $\sim$ & $\sim$ & $\sim$ & $\sim$ \\
& RUS & 564.4 & 96.9 & 34 & 2 \\
StB & SHW & 546.9 & 84.2 & 77 & 13 \\
NDS & ANG & 350 & 3.5 & 29 & 28 \\
& HF & $\sim$ & $\sim$ & $\sim$ & $\sim$ \\
\hline
\end{tabular}

the winter season, with at least two significant snowfalls of approximately $20 \mathrm{~cm}$ and corresponding increases in snow height; however, on both occasions the snow height quickly decreased back to below average levels as the new snow was melted by warm air or rain. Beginning at the end of January 1993, the snow height quickly increased to above 
average and then near-record levels by mid-February. A significant storm in mid-March increased the snow height to a new record high, exceeding the average level by more than $100 \mathrm{~cm}$. A rapid ablation rate of $8.7 \mathrm{~cm}$ per day reduced the snow height to $5 \mathrm{~cm}$ by 31 March 1993. An additional storm increased the snow height to $31 \mathrm{~cm}$ by 2 April 1993, after which ablation resumed, reaching zero on 11 April 1993. Snow height data from the RUS station (Fig. 5c) shows a similar pattern, with the snow height near-zero until the end of January, finally exceeding $7 \mathrm{~cm}$ for the remainder of the winter on 27 January 1993. The snow height quickly increased to record levels by mid-February, and stayed there until a rapid melt reduced the snow height to zero on 13 April 1993. Snow height data are missing for much of the second half of April, although one day (23 April 1993) shows a snow height of $5 \mathrm{~cm}$.

The winter of 1995-1996 is ranked 53rd of $77 \mathrm{yr}$ for short winter precipitation at the SHW weather station (31.5\%; Table 4); however, the long winter is ranked much higher at $84.2 \%$, with greater than $500 \mathrm{~mm}$ of precipitation (Table 5). Snow began accumulating on the ground relatively early in the fall of 1995 (Fig. 5d), reaching a record high by 15 November 1995, and remaining at or near record levels until 22 December 1995. One ablation event in January brought the snow height to below average level, and the spring ablation period began early, with snow heights receding by midFebruary, and reaching zero (except for two subsequent small snowfalls) by 5 April 1996.

Both the long and short winter precipitation are very lowranking for the 2010 NDS landslide at the ANG station, only exceeding $21.4 \%$ and $3.5 \%$ of other winters in the record, respectively (Tables 4,5 ). There are many missing data in the HF record for 2010, and therefore we cannot calculate the winter precipitation accurately; however, we can estimate the missing values based on the ANG record. There were approximately $25 \mathrm{~mm}$ of precipitation at ANG on the missing days for HF, which when added to the HF record means it only exceeds two or three other winters in the record. This suggests that the winter period 2009-2010 was very dry at $\mathrm{HF}$, even if there was significant precipitation on the days with missing data. There are no snow height records for HF, although we do have these for ANG. Figure 5e shows the snow height evolution for ANG compared to maximum and average from the record. Zero or near zero snow heights persisted until 7 December 2009. Two large snowfalls brought the snow height to near its peak at $36 \mathrm{~cm}$ by 5 January 2010 , while the maximum in the record for that day was $59 \mathrm{~cm}$. Average or slightly above average values were recorded for the following three months. Snow height returned to zero by 12 March 2010, much earlier than average. The winter season 2009-2010 is characterized by a shorter than normal period with snow on the ground, but mostly above average snow height from mid-December to early March. Snow accumulated and ablated very rapidly, compared to average.

\section{Discussion}

These results for SJV suggest that both a higher than normal winter precipitation and a highly ranked short-term rain event contributed to the triggering and release slide. Some might argue that the smaller, deep-seated slide on 28 April 1971 was an important cause or trigger of the larger event, in which case the shorter-term precipitation event may simply be coincidental. We expect that the snowpack evolution at YBG resulted in a relatively deep ground frost penetration because of the lack of a thick snow layer insulating the ground from below freezing air temperatures. The average snow heights recorded in the spring likely resulted in normal timing of the onset of ground-thawing following snowmelt, although presumably this took longer than normal given the deep penetration of the ground frost.

Tavenas et al. (1971) stated that the SJV landslide occurred just after the first heavy rainfall following the thaw of the soil. They also report that extensive areas of standing surface water within the snow-free slide area drained rapidly overnight 23-24 April 1971. One possible explanation for the sudden drainage is that it coincided with the thaw of the ground frost, leading to a sudden increase in the hydraulic conductivity of the surficial soils and to the rapid infiltration of the surface water. Given the very low snow cover in the early winter (Fig. 5a) and the likely deeper frost penetration, the thaw may have occurred later than normal, thus restricting infiltration of melt water and precipitation. Those excess waters appear to have been in storage as surface water in flooded areas, but may have been mobilized at the time of the soil thaw. That infiltration, combined with the heavy rains in the days leading up to the landslide, likely led to the destabilization of the soil as outlined by Tavenas et al. (1971). The bedrock surface below forms a valley feature, which may have led to funneling of ground waters from a large catchment into the area of the slide during the infiltration event following the ground thaw, further destabilizing the clay (Tavenas et al., 1971).

Given the occurrence of a smaller deep-seated landslide on 28 April 1971 within the SJV site, it may be useful to test an offset antecedent interval in order to evaluate the possibility that the earlier slide was related mechanistically to the larger event. Alternatively, both slides could have simply responded similarly to similar triggering weather conditions.

The most notable variable for 1970-1971 at the YOW weather station related to the SN slide was the very high, record-setting winter precipitation. A closer inspection of the snow height records for the YOW station shows that there was no major rain or snowmelt event during the winter, which means that most of the winter precipitation was available for infiltration or runoff during the spring ablation event. The snow height was average or below until early December, which may have allowed for a deeper than normal frost penetration in the fall, although the thick insulating layer of snow beginning in December may have inhibited the formation of 
ground-frost for much of the remainder of the winter. The wettest winter in the record (2007-2008) had no landslide event, although there was a significant rain and melt in the month of January which may have reduced the surface water balance after the melt. However, the peak snow height in 2008 did exceed that in 1971, suggesting that precipitation and snow height alone may not describe fully the influence of winter weather on the likelihood of landslides in the area of the South Nation River.

A short-duration, local storm or squall may have been a factor in for the SN slide, as Eden et al. (1971) report that a strong thunderstorm was occurring at the time of the landslide (approximately $1100 \mathrm{~h}$ ). This localized storm may not have been recorded at YOW. While difficult to manage quantitatively, qualitatively at least we expect that the one-day antecedent precipitation would have been ranked much higher had the thunderstorm been recorded.

Eden et al. (1971) note nearby groundwater and river level observations showing that both water table and river had risen prior to the landslide (due to snowmelt and precipitation), but only the river level had dropped at the time of the landslide, with drawdown of the groundwater restricted by the low permeability of the clays. Standing water at the surface would suggest that the entire soil column was saturated at the time of the landslide. This observation suggests that the record-setting winter precipitation and snowpack available at melt, in combination with a heavy, short-duration storm, likely contributed to the triggering of the landslide. The timing of the ground frost thaw is not known, although the temperature and snowpack evolution suggest that 1971 would have been a typical year for ground frost conditions.

The antecedent precipitation intervals at YOW that were available (one to 28 days) for LMX ranked highly. While subject to the same limitations due to distance from the weather station as the $\mathrm{SN}$ event, these values suggest that the month leading up to the LMX event was very wet compared to most other days in the record, although not the wettest in the record.

Results for LMX from the RUS station indicate that the several weeks leading up to the landslide were wetter than a typical year, although again not the wettest. The winter precipitation observed at RUS for the short winter interval was ranked 7th in the record, which does not include the very wet 1970-1971 winter. For the long winter interval, however, 1992-1993 ranks second, exceeded by only 2007-2008 in the record. Precipitation at the end of the long winter period (15-30 April) fell as rain. These results show that very heavy winter precipitation, which fell almost entirely as snow and lacked a major winter melt event, may have contributed to the landslide trigger. Closer inspection of the winter precipitation record shows that most of the near-record snowfall occurred in March and early April (Fig. 5c), with the snowpack height well below average until the first week of February. This very low snowpack for the cold months of December and January likely resulted in much deeper than normal frost penetration and ground temperatures, and a later than normal ground thaw.

Evans and Brooks (1994) discounted effects of flooding or spring runoff in the South Nation River as a trigger for the LMX slide. They noted rain that fell in the shorter antecedent intervals leading up to the slide. Notably, the LMX slide occurred over one month later in the calendar year than the SN event (i.e. 16 May versus 20 June), but is located in similar soils less than $5 \mathrm{~km}$ away. Both 1970-1971 and 1992-1993 had very high snowfalls and snow heights, and relatively high-ranking - but not record setting - short-term antecedent precipitation. In fact, the main difference between the two slides observed in this study is the timing of the snow accumulation and its implied effect on frost depths, with 19701971 being typical, and 1993-1994 probably having a very deep frost penetration and a corresponding late thaw. This suggests that frost depth and timing of the ground thaw has an important influence on the timing of landslides, in addition to the very high winter precipitation, snowfall, and snow height at melt.

The seven-day antecedent precipitation at SHW for the day of the StB landslide exceeded approximately $99 \%$ of days in the record, suggesting that the exceptionally wet week or more leading up to the landslide had some influence on its triggering, although at least one percent of days in the record did have higher seven-day antecedent precipitation. The winter of 1995-1996 ranked low in the record; however, the snowpack height records show that the late fall of 1995 was very snowy, with snows arriving early and remaining at a record-setting height from mid-November to mid-December. While the record is short (1980-1996 inclusive), these observations suggest that there was significant ground insulation in the early winter, and most likely very limited frostpenetration. This shallow frost would have begun to thaw early as well, as snowpack ablation began in early March of 1996 and was complete much earlier than average on 5 April. The unusual early and late winter conditions likely led to very shallow frost penetration and an early ground thaw, which meant that the exceptionally wet period beginning after the first week of April had a better chance of infiltrating and destabilizing the soil.

Evans et al. (1997) stated that the StB landslide occurred because of heavy rainfall, although they did not provide further details. In this study, we have shown that the week leading up to the landslide had very heavy precipitation, although it was not the wettest period in the record. None of the other weather variables tested here are exceptional for this event, except for the very early snow accumulation and the very early season release of the slide in late April. The StB site has a similar overlying sand layer as found at SN and LMX sites, which suggests that ground frost development and thaw may behave similarly and have a similar impact on soil stability.

The NDS slide occurred less than one day following a relatively large earthquake, centred only $14 \mathrm{~km}$ away. In many 
cases no further analysis of the trigger would be required, i.e. the earthquake would be assumed to have directly or indirectly triggered the slide. Our results suggest that heavy precipitation may have had an additional influence in the case of the NDS slide. Every antecedent interval between two and seven days at the HF station were very highly ranked. In particular, the two-day interval - which includes the period between the earthquake and the slide release - was one of the wettest on record. We expect that given the proximity of the slide site and the weather station at HF that the recorded rainfall did actually occur in the area of the slide. The week leading up to this landslide, earthquake notwithstanding, was one of the wettest in the record for the area around NDS, and compared to the other events we studied probably has the most notable short duration precipitation correlation. This is also the only event with a close temporal link to an earthquake. It appears that some combination of earthquake energy and precipitation led to this landslide, and may partly explain the delay between the earthquake and the release of the landslide.

Despite the notable temporal correlations we found, mostly confirming the published case studies, it is important to recognize that the mechanism through which precipitation or snowmelt may act on a potentially unstable area is unknown, and certainly debatable. As the causative mechanism is unclear, it remains possible that the correlations are coincidental rather than causative.

The role of ground frost in the timing of each of these landslide events may be due to several factors. First, because of precipitation and reduced evapotranspiration, groundwater recharge in fall often leads to saturated surface soils in the early winter. Once frozen, this water is effectively sequestered until the spring thaw. With the thaw typically occurring from the surface down, this water supply would remain in storage until the thaw was complete. At that time, it would affect the soils in the same manner as a large rain event would, although in this case the conductivity of the surface would not control the amount of infiltration compared to runoff, since this water is already in the soil. This effect might be enhanced if ice-lenses formed in the soil during freezing, as these would be locations of maximum water content (e.g. Penner, 1961). Second, frozen (saturated) glaciomarine "clay" or overlying sandy layers would act as an impermeable aquitard, restricting vertical infiltration of precipitation or melt water until the thaw was complete from the surface down (Penner, 1970). At the time of the thaw, the hydraulic conductivity of the surface soils would suddenly increase, and any excess waters stored at or near the surface would be added to the groundwater system, along with the soil moisture liberated as described above. Scott (2003) suggests that the "reservoir principle" of Denness (1972) may be effective even without frozen soils, since water stored in the permeable sandy or cracked surface layer might feed the less permeable sensitive clay in a steady-state fashion for much longer than if it was simply subject to runoff and melt. In addition, he suggests that the saturation of the surface soils could establish hydraulic continuity in the soil column, leading to a rapid increase in pore pressures at depth in the clay, which would be sustained while the surficial strata slowly drained. The reservoir effect would begin operation as soon as the ground frost thaw is complete, when both the hydraulic conductivity of the surface soils suddenly increases and any moisture sequestered there is then released.

Even with a delay of days or weeks following the thaw, a short-duration heavy precipitation event might extend the period of saturation or high pore pressures and thereby trigger the failure process. This mechanism would require that there be excess surface waters available at the time of ground thaw, but would also need further heavy precipitation in the spring after the thaw. The time at which critical instability in the sensitive clay is reached would therefore depend on the timing of the ground thaw and some unknown combination of the water balance between that trapped in the soil over winter, available from snowmelt, and resulting from springtime precipitation. None of these would need to be extreme or record values, just as we observed in this study. While qualitative at best, the "typical" timing of the SN and SJV slide, the very late timing of the LMX slide, and the very early timing of the StB slide may serve to illustrate this point, since each appears to have had a corresponding typical (SN and SJV), late (LMX) and early (StB) ground frost release. The snowpack evolution for the winter of 2007-2008 also serves to illustrate this concept. In the area east of Ottawa, Ontario (i.e. for SN and LMX sites), that winter was the wettest on record. It had record high snow in the early winter, but a major rain and ablation event in early January that reduced the snowpack to zero. Record snow height accumulated again by March, followed by an average spring melt. This was a very atypical pattern, and likely led to atypical ground frost development and possibly an ice crust at the snow-soil interface, or some similar feature which affected the runoff and infiltration conditions in spring.

\section{Conclusions}

Our study of a large number of antecedent precipitation variables for days with large landslides shows that record-setting intervals are never associated with landslide events, at least for the slides and arbitrary intervals we chose. Each landslide event did have several high-ranking antecedent intervals, although a unique set occurred for each slide, including those related spatially or temporally. Near record-setting precipitation in winter occurred in two cases, although a secondary, more direct mechanism is required (e.g. rapid melting) since snow alone is not expected to trigger landslides directly. Heavy winter snowfalls relative to the long-term record did not occur in two other cases.

Although several of the antecedent or winter precipitation intervals were highly ranked in the records for each landslide, 
none can be shown to represent the sole trigger. While the mechanism by which heavy rain over both short and long antecedent intervals affects the stability of the soil may be debatable, it is clear from previous studies and from our results that a steady supply of surface waters from precipitation or snowmelt are a necessary precondition for landsliding. Others have suggested that regional factors such as funneling or focusing of groundwater due to bedrock topography (Tavenas et al., 1971) or changes in groundwater regimes due to valley formation (Lefebvre, 1986) may also play a role. There are likely several other lurking or hidden variables involved in the triggering or direct cause of large landslides in sensitive clay; we propose that ground frost conditions and timing of the thaw coincident with some other triggering agent could be one of these in eastern Canada.

The case of the NDS landslide highlights the notion of multi-factor triggering for large landslides in Champlain clay, given that two completely independent potential triggering events occurred just before the slide occurred. In that case the earthquake and precipitation events may have interacted to trigger the slide, such that if no rain had fallen the slide may not have occurred. Alternatively, this could represent a coincidence, although given our results showing a clear correlation between large landslides and high-ranking precipitation in other cases, we suspect that both were required here.

Studies on frost in Champlain clay generally relate to engineering problems with frost heave, adfreezing, etc. (e.g. Penner, 1961, 1970; Penner and Burn, 1978). To understand better the role of the interaction of ground frost with precipitation and snowmelt in the triggering of large earthflows or flowslides in sensitive clay, more data regarding the timing of frost formation and thaw are required. In addition, if the role of air temperatures and snow cover on frost conditions could be modeled more precisely for locations susceptible to slides, this could improve the forecasting or prediction of when large landslides are likely to occur. A better understanding of the triggers of these destructive and often dangerous events could drive refinements to understanding the mechanics of the failures that cause them.

Acknowledgements. This manuscript was improved greatly by two very thorough reviewers. The Railway Ground Hazards Research Program (RGRHP), a collaborative effort funded by NSERC, CN Rail, CP Rail, and Transport Canada, supported this research. We wish to thank Environment Canada for supporting research by making historical climate and weather data freely available. We are grateful to Pete Quinn for a very constructive review of an earlier draft of this manuscript. Heather Crowe, Greg Brooks, Jim Hunter, Rejean Couture, Didier Perret, and Peter Bobrowski from the Geological Survey of Canada continue to be very generous with sharing their knowledge and expertise in sensitive clay landslides.

Edited by: A. Günther

Reviewed by: J. O. Larsen and D. Perret

\section{References}

Bjerrum, L.: Stability of natural slopes in quick clay, Geotechnique, 5, 101-119, 1955.

Bunce, C.: Risk estimation for railways exposed to landslides, $\mathrm{Ph} . \mathrm{D}$. thesis, University of Alberta, Edmonton, Canada, 417 pp., 2008.

Carson, M.: On the retrogression of landslides in sensitive muddy sediments, Can. Geotech. J., 14, 582-602, 1966.

Conlon, R.: Landslide on the Toulnustouc River, Quebec. Can. Geotech. J., 3, 113-144, 1966.

Crawford, C. and Eden, W.: Nicolet landslide of November, 1955 , Quebec, Engineering Geology Case Histories, 4, 45-50, 1963.

Cruden, D. and Varnes, D.: Landslide Types and Processes, in: Landslides-Investigation and Mitigation, Transportation Research Board Special Report 247, National Research Council, USA, 36-75, 1996.

Demers, D.: Contribution au development du piezocone dans les soils argileux. Ph.D. thesis, Laval University, Quebec, 435 pp., 2001.

Demers, D., Robitaille, D., and Perret, D.: The St. Boniface landslide of April 1996: a large retrogressive landslide in sensitive clay with little flow component, in: Landslides in Theory, Research, and Practice, Thomas Telford, London, 447-452, 2000.

Denness, B.: The reservoir principle of mass movement, Report 72/7, Institute of Geological Sciences, United Kingdom, 13 pp., 1972.

Donovan, J.: On the retrogression of landslides in sensitive muddy sediments: Discussion., Can. Geotech. J., 15, 441-446, 1978.

Eden, W.: Some observations at le Coteau lansdslide, Gatineau, Quebec. Can. Geotech. J., 9, 508-514, 1972.

Eden, W. and Mitchell, R.: The mechanics of landslides in Leda clay, Can. Geotech. J., 7, 285-296, 1970.

Eden, W., Fletcher, E., and Mitchell, R.: South Nation River landslide, 16 May 1971, Can. Geotech. J., 8, 446-451, 1971.

Evans, S. and Brooks, G.: An earthflow in sensitive Champlain Sea sediments at Lemieux, Ontario, June 20, 1993, and its impact on the South Nation River, Can. Geotech. J., 33, 384-394, 1994.

Evans, S., Begin, C., Lawrence, D., Demers, D., Grondin, G., Aylsworth, J., Parent, M., Michaud, Y., and Brooks, G.: A massive retrogressive landslide in sensitive Champlain Sea sediments near Saint-Boniface-de-Shawinigan, Quebec, Canada, April 1996, Landslide News, 10, 17-19, 1997.

Fransham, P. and Gadd, N.: Geological and geomorphological controls of landslides in Ottawa Valley, Ontario, Can. Geotech. J., 14, 531-539, 1977.

Geertsema, M., Cruden, D., and Schwab, J.: A large rapid landslide in sensitive glaciomarine sediments at Mink Creek, northwestern British Columbia, Canada, Eng. Geol., 83, 36-63, 2006.

Guzzetti, F., Peruccacci, S., Rossi, M., and Stark, C.: Rainfall thresholds for the initiation of landslides in central and southern Europe, Meteorol. Atmos. Phys., 98, 239-267, 2007.

Guzzetti, F., Peruccacci, S., Rossi, M., and Stark, P.: The rainfall intensity-duration control of shallow landslides and debris flows: an update, Landslides, 5, 3-17, 2008.

Hugenholtz, C. and Lacelle, D.: Geomorphic controls on landslide activity in Champlain Sea clays along Green's Creek, eastern Ontario, Canada, Geographie physique et Quaternaire, 58, 9-23, 2006.

Hutchinson, J.: A landslide on a thin layer of quick clay at Furre, central Norway, Geotechnique, 11, 69-94, 1961. 
Jakob, M. and Weatherly, H.: A hydroclimatic threshold for landslide initiation on the north shore mountains of Vancouver, British Columbia, Geomorphology, 54, 137-156, 2003.

Jakob, M., Holm, K., Lange, O., and Schwab, J.: Hydrometeorological thresholds for landslide initiation and forest operation shutdowns on the north coast of British Columbia, Landslides, 3, 228-238, 2006.

Karrow, P.: Earthflows in the Grondines and Trois rivieres Areas, Quebec. Can. J. Earth Sci., 9, 561-573, 1972.

Kenney, T. and Drury, P.: Case record of the slope failure that initiated the retrogressive quick-clay landslide at Ullensaker, Norway, Geotechnique, 23, 33-47, 1973.

Lafleur, J. and Lefebvre, G.: Groundwater regime associated with slope stability in Champlain clay deposits. Can. Geotech. J., 17, 44-53, 1980.

Lebuis, J., Robert, J.-M., and Rissmann, P.: Regional mapping of landslide hazard in Quebec, in: Proceedings of the Symposium on Slopes on Soft Clays, Linköping, Sweden, 8-10 March 1982, 1983.

Lefebvre, G.: Slope instability and valley formation in Canadian soft clay deposits, Can. Geotech. J., 23, 261-270, 1986.

Lo, K.: An approach to the problem of progressive failure, Can. Geotech. J., 9, 407-429, 1972.

Locat, A., Leroueil, S., Bernander, S., Demers, D., Locat, J., and Ouehb, L.: Study of a lateral spread failure in an eastern Canada clay deposit in relation with progressive failure: The SaintBarnabe-Nord slide in: Proceedings of the 4th Canadian Conference on Geohazards, Laval, QC, 20-24 May 2008.

Locat, A., Leroueil, S., Bernander, S., Demers, D., and Jostad, H.: Progressive failures in eastern Canadian and Scandinavian sensitive clays, Can. Geotech. J., 48, 1696-1712, 2011.

Mitchell, R. and Markell, A.: Flowsliding in sensitive soils, Can. Geotech. J., 11, 11-31, 1974.

Mitchell, R. and Klugman, M.: Mass instabilities in sensitive Canadian soils, Eng. Geol., 14, 109-134, 1979.

Paul, M.: The mechanics of landslides in Leda clay: Discussion, Can. Geotech. J., 8, 143-148, 1971.

Penner, E.: Ice-grain structure and crystal orientation in an ice-lens from Leda clay, Geol. Soc. Am. Bull., 72, 1575-1571, 1961.

Penner, E.: Frost heaving forces in Leda clay, Can. Geotech. J., 7, 8-16, 1970.

Penner, E. and Burn, K.: Review of engineering behaviour of marine clays in Eastern Canada, Can. Geotech. J., 15, 269-282, 1978.
Perret, D., Mompin, R., Bosse, F., and Demers, D.: Stop 2-5B: The Binette Road earth flow induced by the June 23, 2010 Val-desBois earthquake, in: Deglacial history of the Chaplain Sea basin and implications for urbanization, Joint Annual Meeting GCMAC-SEG-SGA, Ottawa, ON, 25-27 May 2011, Field guide book, Geological Survey of Canada, Open File 6947, 72-74, 2011.

Potvin, J., Pellerin, F., Demers, D., Robitaille, D., La Rochelle, P., and Chagnon, J.-Y.: Revue et investigation du glissement de Saint-Jean-Vianney in: Proceedings of the Annual Conference of the Canadian Geotechnical Society, Calgary, AB, 15-18 September 2001, 2001.

Quigley, R.: Geology, mineralogy, and geochemistry of Canadian soft soils: a geotechnical perspective, Can. Geotech. J., 17, 261$285,1980$.

Quinn, P., Hutchinson, D., Diederichs, M., and Rowe, R.: Regionalscale landslide susceptibility mapping using the weights of evidence method: an example applied to linear infrastructure, Can. Geotech. J., 47, 905-927, 2010.

Quinn, P., Hutchinson, D., Diederichs, M., and Rowe, R.: Characteristics of large landslides in sensitive clay in relation to susceptibility, hazard, and risk, Can. Geotech. J., 48, 1212-1232, $2011 \mathrm{a}$.

Quinn, P., Diederichs, M., Rowe, R., and Hutchinson, D.: A new model for large landslides in sensitive clay using a fracture mechanics approach, Can. Geotech. J., 48, 1151-1162, 2011 b.

Schwab, J., Geertseema, M., and Blais-Stevens, A.: The Khyex river landslide of November 28, 2003, Prince Rupert British Columbia Canada, Landslides, 1, 243-246, 2004.

Scott, J.: A review of the geology and geotechnical characteristics of Champlain Sea clays of the Ottawa River Valley with reference to slope failures, Geological Survey of Canada, Open File Report 4475, 62 pp., 2003.

Tavenas, F., Chagnon, J.-Y., and La Rochelle, P.: The Saint-JeanVianney landlside: Observations and eyewitness accounts, Can. Geotech. J., 8, 463-478, 1971.

Torrance, J.: Towards a general model of quick clay development, Sedimentology, 30, 547-555, 1983.

Torrance, J.: Physical, chemical and mineralogical influences on the rheology of remoulded low-activity sensitive marine clay, Appl. Clay Sci., 14, 199-223, 1999.

Wieczorek, G.: Landslide triggering mechanisms, in: LandslidesInvestigation and Mitigation, Transportation Research Board Special Report 247, National Research Council, USA, 76-90, 1996. 